\title{
Egalitarianism in the Mabadi Al-Irsyad: An Analytical Study on the Concept of Al-Musawah
}

\author{
Faisol Nasar Bin Madi ${ }^{1} \&$ Aminullah Elhady ${ }^{2}$ \\ ${ }^{1}$ State Institute for Islamic Studies (IAIN) Jember, Indonesia \\ Correspondence: Aminullah Elhady. E-mail: aminelhady@iain-jember.ac.id
}

Received: August 4, 2020

doi:10.5539/ass.v16n11p24
Accepted: September 25, 2020

Online Published: October 31, 2020

URL: https://doi.org/10.5539/ass.v16n11p24

\begin{abstract}
Islamic teachings place all human beings physiologically and sociologically in the same status even though they have different backgrounds. This article analyzes the concept of al-musawah (equality) in Mabadi (basic principles) of Al-Irsyad, an Islamic social organization in Indonesia, most of whose members are of Arab descent. This study has an urgency to find a common thread between the inclusion of the concept of al-musawah in Mabadi and the circumstances behind it, as well as its relevance to plural life among Indonesian Arab descendants at present. This study was conducted using documentary and historical analysis methods. From this research it was found that the concept of al-musawah was included in Mabadi Al-Irsyad based on social settings, there was an assumption regarding differences in social stratification in Arab community originating from Hadramaut. Al-Irsyad formulated the concept of egalitarianism in Mabadi, which until now is still maintained. It is believed that the concept of al-musawah is compatible with the concept of humanism in Islam.
\end{abstract}

Keywords: egalitarianism, social stratification, humanism

\section{Introduction}

Mankind in the Abrahamic religious texts is said to have descended from a common ancestor, namely Adam. Along with the changing times and ages, mankind developed into tribes and nations spread to various parts of the world into a diverse people. The diversity in social life is a natural reality. Ethnic, cultural, linguistic, skin color differences are part of that diversity. Although it is a natural phenomenon, some conflicts arise as a result of these differences. That's why instilling awareness about differences becomes something important.

Al-Irsyad is one of the Islamic social organizations in Indonesia. It was founded in 6th of September 1914 with the full name Jam 'iyah Al-Ishlah wal-Irsyad Al-Islamiyah, long before Indonesian independence in 1945. As a movement and organization, Al-Irsyad was designed to stand on an ideology which they named Mabadi, plural form of the word mabda, literally means "starting place". Hereinafter referred to as Mabadi or Mabadi al-Irsyad. Organizationally it means the basic rules, which in this case it functions as a method and perspective to understand and practice the teachings of Islam contained in the Quran and the Prophet's traditions, as the main source of the religious teachings.

There are 8 teaching points in the Mabadi Al-Irsyad document, as an interpretation to advance individuals, people, and the nation. The formula is concise as follows: legal sources, principles of faith and creed, principles of worship, principles of morality and ethics, principles of equality, development of science, modernity for expediency, and Islamic brotherhood in the struggle. (PP Al-Irsyad, 2018).

The focus of this study is on the principle of equality what so called al-musawah, which is a concept of social life and horizontal relations. The concept stipulates the need to instill egalitarianism in all its members specifically, and in all society in general.

Al-Musawah or egalitarianism as an inter-human equality is absolutely needed in social life. Instilling an attitude and egalitarian nature to all different individuals and groups makes worldly life in peace and tranquility. Conceptually, al-musawah is one of the elements of da'wah (Islamic preaching) brought by Al-Irsyad. One mission is to instill moral messages in accordance with Islamic principles. Specifically in the case of egalitarianism, the founder of this organization firmly states that one human being is equal to another. (PP Al-Irsyad, 2000).

As an Islamic organization, Al-Irsyad places the concept of al-musawah as something very important and 
therefore included in the basic rules of the organization. This is as a consequence of the principle of organization that preserves the Prophet's tradition and follows the life attitude of the Salaf generation. Among the important things that concern them is the concept of insaniyyah (Islamic humanism) which is a central part of the concept of al-musawah.

This study was conducted to analyze the concept of al-musawah in the view of Al-Irsyad and relate it to the concept of humanism, which includes: The concept of al-Musawah in the perspective of Al-Irsyad, the historical context of the emergence of al-musawah, and its relation to the humanism.

\section{Purpose of the Study and Research Question}

Indonesia consists of population that has diversity. The territory of this country stretches $8514 \mathrm{~km}$ from the town of Sabang on the northern tip of the island of Sumatra to Merauke in Papua, is inhabited by more than 269 million people. They consist of about 300 ethnic groups, 1340 tribes, and 737 languages. (Demografi Indonesia, 2020).

Among the ethnic groups of Indonesia are Arab descendants, whose ancestors have entered this area for centuries. They came from Hadramaut (hence they have been known as Hadrami) to the Archipelago together after the entry of Islam in the seventh century. The mission of their arrival was to trade and spread Islam. (Isnaeni, 2020).

Along with the development of time and the emergence of political disputes in the Middle East, The Hadhramis frequently suffered from conflicts among them, because of a highly stratified community, namely the Sayyid (the Sadah grup) and non-Sayyid, which among the causes is the prohibition of unequal marriage (non-kafa'ah), which stipulates that a sayyidah (female) can only be married by a sayyid (male). In the early twentieth century, non-Sayyid figures opposed it, so the issue of kafa'ah led to a long-standing conflict between the Hadhramis in Indonesia and the deep conflict between the two groups erupted leading to their division along social and political lines. The Sadah created the Jami'at al-Khair, while the non-Sadah created Al-Irsyad. (Jahroni, 2020: 12)

Al-Irsyad is one of the major Islamic religious organizations in Indonesia. Different from other Islamic organizations, Al-Irsyad consisted mostly of members of Arab descent, especially from Hadramaut. Although actually Al-Irsyad is a national Islamic organization, because one of the requirements to become a member of Al-Irsyad is "an Indonesian citizen who is Muslim and has grown up", as stated in its basic rules article 11 paragraph 2. (PP Al-Irsyad, 2018: 4).

There is a perception that there are social class distinctions in this group. Indeed, this perception had arisen in the early days of Al-Irsyad, but because there are still many such assumptions appear in the educated people, especially according to the common. As there is special treatment of Arab descendants who bear the title Sayyid and Habib. That is why this study still has urgency.

The emergence of the concept of al-musawah in the basic rules of the organization is inseparable from the social reality that occurs in the organizational community, namely the growth of feudalistic attitudes brought by the Hadramaut Arabs and developed in Indonesia. The pioneers of the organization viewed that all humans have equality according to the basic principles of Islam, both those listed in the Quran and those taught by the Prophet Muhammad. For Al-Irsyad, there is a close relationship between the concept of al-musawah and humanism, which is to uphold human dignity and glory, regardless the background of ethnic, culture, nation, language, or national lines. All are equal and have the same position.

The research questions are as follows: (1) the meaning of the concept of al-musawah in Mabadi Al-Irsyad, (2) the socio-historical background of the emergence of al-musawah, (3) the correlation between the concept of al-musawah with humanism in Islam.

\section{Methodology}

The method to study this problem is documentary and historical analysis, based on sources of relevant information, both primary and secondary data. This method relies on four steps namely: data collection, verification of sources, interpretation, and historiography.

To explore the data it used a sociological approach to find the motives and factors behind an event. In this case, to find out how was the situation and the factors driving the drafting of the concept of al-musawah in Mabadi Al-Irsyad.

\section{Discussion}

a. The Concept of Al-Musawah 
The word al-musawah literally means to equalize. (Munawwir, 2007: 186). In the book of Mufradat Alfaz al-Quran, the word is interpreted as balance in all things, such as colour, shape, size, or behavior. (Al-Asfahani, 2013: 439).

In terminology, al-musawah is negating all forms of difference, eliminating barriers of difference in any aspect. As well as everyone to another is same, both in terms of religion, law, or nationality. Likewise in the field of religious affairs and worldly one.

Based on the description, al-musawah is a norm that aims to eliminate all kinds of discrimination due to ethnic, religious, linguistic or cultural differences.

b. Background to the Emergence of the Concept of al-Musawah

There is a general view in the public area, that the kinship system is related to the social strata. In many groups there are social classifications, for example in Balinese people in Indonesia, as the influence of Hindu culture, community classification is based on heredity. Hindu texts refer varna to classify the society into four main categories - the Brahmins: consists of priests and teachers; the Kshatriyas: kings, warriors, and administrators; the Vaishyas: farmers, traders, merchants, artisans; and the Shudras: service providers and labourers. (Lumen, 2020). The Brahmins have the highest position in the structure of society because their degree is related to clergy. The second highest degree Kshatriyas, who works as state officials and royal descendants. The Vaishyas consist of traffickers, entrepreneurs, or craftsmen. The Sudras are the lowest, consist of workers and unlicensed people, who serves for the 3 groups higher. (Anwar, 2016: 2).

Social stratification has a wide influence on social life. Among the Arab descent in Indonesia, especially those from Hadramaut, there are social groups as found in their ancestral land. According to Shahab (2005: 127), there are 4 layers of community of Arab descent, namely the Sadah, the Masyaikh, the Qabail, and the Masakin or Duafa.

The concept of al-musawah in Al-Irsyad arose from a socio-historical background relating to the innate social shock of the Middle East, which is a critique of the Middle Eastern habits that are very fanatical about social classes, especially with regard to nasabiyah (kinship relations).

The social stratification of the Arab community from Hadramaut in Indonesia follows the general pattern prevailing in their home country. The Sayyid (Sadah) group occupies the highest and most respected position because they are believed to be a descendant of the Prophet Muhammad from the path of his daughter Fatimah. (Perserikatan Al-Irsyad, 1932: 17).

The habit of the Hadrami, especially among the Alawiyyin group is to cult the Sayyids who have lineage to the Prophet. In their doctrine, the sayyids must be respected and their hands must be kissed, whether they are kids, or who have grown up, even if they have a bad temper. The way of culting the Alawiyyin is by giving them the title of Sayyid or Habib. (Al-Bakri, 1960: 224). Until this time such special respectation still exists and is developing in Indonesia.

Umar bin Salim al-Attas al-Alawi, an expert from the Alawiyyin lineage, emphasized the forbidden marriages of the Alawiyyin generation with others, although on the basis of his guardian's blessing. (Al-Bakri, 1960: 224). While Al-Surkati had the opposite view, through its fatwa known as the "Fatwa Solo" mentioned equality among all Muslims, and did not recognized discrimination based on descent, blood, position or wealth. (Mughofar, 2016).

The social settings of Indonesian people also affect the Arab descendants identity, which the sharp social stratification such as those in Hadramaut are no longer possible to be developed in Indonesia. The movement and the rise of Indonesian nationalism had a great influence on the patterns and social attitudes of immigrants from the Arabs, thus encouraging the emergence of an Indonesian Arab modernism movement. The result was the narrowing of the Arabs into two groups, namely the Ba-alwi group (Alawiyyin) and Al-Irsyad group which called themselves Irsyadiyyin. Actually these two groups still reflect groupings based on descent, where the first feels as a descendant of the Prophet, and the second considers themselves to be more open and moderate Arab descendants. (Naji: 64).

Indirectly such conditions are detrimental to some groups and benefit other groups. Therefore, Al-Surkati an important figure of Al-Irsyad emphasized the importance of growing the attitudes and nature of al-musawah in each individual, so that awareness of mutual respect and fairness. Conceptually, al-musawah is the most important part of religious life, apart from the purpose of the relegation of religion, there is a strong spirit of being able to coexist peacefully in a pluralistic life, as mentioned in the Quran, chapter of Al-Hujurat: 13, that every human being is essentially created from one origin. (PP Al-Irsyad, 2000: 59). 
The meaning of the verse explained by Al-Surkati in his fatwa. It is indeed a classification between ethnicities and nations, or the naming of those who differ from one another, is intended so that they know each other. Thus it is as the naming of each individual of the same descendant is to distinguish between one and another. Just as there is separation between the ocean, land, and countries, there is really no virtue except as proven by excellence and achievement. (Naji: 48).

In Mabadi Al-Irsyad stated: "Al-Musawah is a principle of meritocracy (equality) and egalitarianism, namely equality of the humans before the law or before Allah. And the virtue of one can only be achieved through education and teaching that provides him a right life in religion. This can be seen as software of social systems which is then developed in a modern order of protecting human rights and rejects all forms of human exploitation of others, eliminating racial discrimination, eliminating forms of slavery or social stratification based on geneology for the sake of making it more possible for a just order.” (PP Al-Irsyad, 2000: 64).

The principle of egalitarianism must be embedded in each individual, so that he feels equal with others. Naturally, it cannot be denied that differences of humans are necessity, but it is only a sign of identity between one another. (Naji: 34-35). Within everyone there are two choices of status, namely: the status of lineage and the status of quality and capacity, described as follows.

(1) Status of Lineage

Lineage status is one's status of blood relation, obtained through the origin of descent, skin color, and ethnicity. Such a status cannot be changed because of the development result of a biological sequence. Therefore, this status can not be used as a basis for measuring an achievement. According to the spirit of Islam, there is no difference in a one's piety caused by differences in lineage, ethnicity, or language. This is in accordance with the statement of the Prophet: "O people! Your Lord is one, and your ancestor is one, remember! There is no advantage for Arabs over non-Arabs and for non-Arabs over Arabs, there is no advantage for red people over black people, nor black people over red people, except with piety." (Musnad Ahmad, No. 23489).

(2) Status of Quality and Capacity

This discussion of the second status is relevant to the principle of fastabiq al-khairat in the Quran, which means "competing for good". That there is a suggestion and encouragement for everyone to compete for good, because with the existence of good behavior that he will have superior qualities and capacities compared to others.

The position of people who have knowledge and good deeds is, as narrated by Ibn Asakir: "The most important is a believer who has knowledge. If he is needed he benefits, and if he is not needed by other he benefit himself". (Asakir, 2015: 303).

There are two principles in the statement, knowledge and expediency. The status comes from the quality and is obtained based on the superiority of one's piety and knowledge. Likewise history has noted, that the superiority of Muslims to achieve the glory of civilization for approximately seven centuries is a result of their ability in the field of science and civilization.

\section{c. Correlation between al-Musawah and Humanism}

Basically, al-musawah is the concept of upholding human dignity and glory, as the concept of humanism is oriented towards humanizing humans. The concept of humanism in the Islamic perspective is different from humanism in general. Humanism aims to foster individual creative development and criticism as well as individual interpretations in contrast to religious traditions and authority.

Humanism can also be understood as an effort to elevate human values based on four elements of policy, namely; wisdom, courage, simplicity and justice. Humanism aims to eliminate all forms of discrimination and equalize people regardless of people, race, nation, culture, religion, and others. (Ihsan, 1996: 53-54)

Humanism in Islam is intended to name human glorification which is called insaniyah in Arabic. Lexically, the word insaniyah is derived from the word insan which shows the meaning of man with all his totality of body and soul. (Mursi, 1995: 264-265).

According to Quraish Shihab (1996:278-280), the word insan refers to people who have attitudes as a result of awareness of reasoning so that they are gentle and able to adapt with realities of life and their environment. Furthermore (Ahmad, 1985:12), the concept of insaniyah is intended in Islam as a concept that fights for human glory.

Islamic humanism is actually which is based on Islamic teachings, which is different in meaning from Western humanism. Islamic humanism not only relies on ratio ( $a q l$ ) but also refers to the religious arguments (al-adillah al-shar'iyah) in answering human needs. This characteristic distinguishes, although there are similarities in 
humanitarian goals.

Universally, the principle of Islamic humanism aims to glorify humans based on the five points (al-kulliyat al-khams) as the main goal of religion (maqasid al-shari 'ah),: maintaining the glory of belief, safeguarding the soul, maintaining freedom of thought, preserving offspring, and preserving material validity. (Al-Badawi, 2000).

In the tradition of the people of Arabic descent, there is a doctrine of the classification of the people, which therefore arises the differences of the people. According to Al-Surkati, all forms of discrimination against anyone are not in accordance with the spirit of Islamic teachings. The tradition of Arab descendants of old habits must be abolished, because in fact all humans are the same, the only dishtinguisher is one's quality. (Naji: 34-35).

\section{d. The implications of al-Musawah in Multiple Life}

Egalitarianism is a reality that is needed by humans, with these principles the balance of life in the world can be realized. The phenomenon of conflict between individuals or groups can be subsided because of the principle of egalitarianism, so that a peaceful life comes. In the view of Islam, the peak of Allah's grace to all mankind is the presence of the Prophets and Apostles who convey the holy messages to improve human life, from various aspects.

The presence of Islam, in addition to teaching the concept of divinity also, brings the mission of the realization of the benefit of mankind, as referred to the maqasid al-shari'ah to safeguard and guarantee individual and group rights. As the words of God in the Holy Quran 57: 25. Textually, the verse shows an egalitarian principle for all humanity which is manifested in a just manner, as is the main mission of the Prophets and Apostles. Likewise the mission carried by the Prophet Muhammad, namely the mission of rahmat li al- 'alamin. With his arrival various forms of discrimination were erased. People who live under his leadership get the same attention and rights, and do not discriminate against ethnicity, color, language and culture. These things are included in the Medina Charter. (Al-Buti, 1980: 193).

Basically egalitarianism and justice are the implications of individual or group piety embedded in their souls, as confirmed in the Holy Quran, 5: 8. Ibn Kathir stated that the verse shows the necessity of being fair to anyone, no matter who faces are relatives, friends or even enemies. (Kathir, 1992, III: 62). Because, justice is a balanced barometer of truth or an attitude of mediation on the basis of the truth itself, without being hindered by any bond. While Nurcholish Madjid stated that theological justice is closely related to ihsan, namely the desire to do good for fellow human beings with sincerity, whose all born and inner attitudes are never a secret before Him. (Madjid, 1992: 115).

The principle of shura (deliberation) in Islam is a form of implementation of the concept of egalitarianism which is oriented to the enforcement of justice. Egalitarianism as an understanding of life based on the view of the similarity of human degrees, is operationally reflected in the principle of shura whose mechanism of action lies in "being heard" and "hearing". In this context, Nurcholish Madjid mentioned that deliberation contains the meaning of mutuality, a reciprocal relationship, that is the relationship giving signals to each other about what is right and good. (Madjid, 1994: 253).

The similarity of human degrees based on the quality of piety binds them in the awareness of the morality of universal brotherhood. Religion serves to remind its similarity, as a basis for friendship, brotherhood, and help in realizing social justice.

It was in the fragile systems of economy, society and culture in the past, God revealed His verses to make people pay attention to the symptoms of poverty, misery and oppression. The verses encourage people to do good to the poor and orphans.

The Quran stated there are three attitudes of indifference to social life: ignoring the poor, injustice and misuse of inharitance assets, and greed for property. Social inadequacy is maybe caused by blunt spiritual morals.

Egalitarian attitude have implications in social life as follows: (1) Al-musawah is the main key in order to bring about mutual respect between one and another, or between groups, (2) The emergence of the nature of mercy, loving others, as social being, (3) The main principle of al-musawah is the necessity of being fair to oneself and others, (4) There is an Islamic doctrine in al-musawah which states that human glory is not due to ethnicity, color, language, or lineage. The only factor that distinguishes them is the piety.

\section{Conclusion}

The social equality is one of the basic teachings of Islam that is universal, as the nature of Islam, it applies to every human being, in any part of the world, and throughout the lifetime of this world. Therefore efforts to create or maintain social stratification based on blood lines or lineages are contrary to the principles of Islamic 
teachings.

Based on the description, it can be concluded that al-musawah or equality is a concept of growing egalitarian attitudes in each individual or social group. Historically, the emergence of the concept of al-musawah in Mabadi Al-Irsyad was a response to the social situation of its time, namely the existence of a feudalistic attitude with the presumption of social class differences caused by lineage or heredity.

It was found that there is a common thread between the concept of al-musawah and humanism, i.e. the attitude of upholding the dignity and human dignity, without being influenced by consideration of ethnicity, lineage, culture, nationality, or languages, because all humans originate from the same ancestor and material same standard. Therefore disputes among Muslims regarding this issue should be returned to the basic principles of their religious teachings.

\section{References}

Ahmad, I. A. (1985). Nahw Tatwir al-Idarah al-Madrasiyyah: Dirasat Nazariyyah wa Midaniyyah. Dar al-Matbu'at al-Jadidah.

Ahmad, I. H. "Musnad Ahmad" No. 23489. Al-Maktabah al-Shamela (Version 3.48). Retrieved from http://shamela.ws.

Al-Asfahani, R. (2013). Mu 'jam Mufradat Alfaz al-Qur'an. Al-Kutub al-'Ilmiyah.

Al-Badawi, Y. A. M. (2000). Maqashid al-Shari'ah 'Inda Ibn Taimiyah. Dar al-Nafa'is.

Al-Bakri, S. (1960). Hadramaut wa 'Adn. Maktabah al-Irsyad.

Al-Buti, R. (1980). Fiqh al-Sirah, Dirasat Manhajiyyah li Sirat al-Mustafa. Dar al-Fikr.

Al-Qayyim, A. (1973). I'lam al-Muwaqqiin. Dar al-Jail.

Anwar. (2016). Ini Kan Bukan Bali: Interaksi Antar-Kasta Masyarakat Transmigran di Desa Kertoraharjo, Kabupaten Luwu Timur, Sulawesi Selatan. Etnosia Jurnal Etnografi Indonesia, 1(2).

Asakir, I. (2015). Tarikh Dimasq. Dar al-Kutub.

Demografi Indonesia. (2020). Retrieved July 10, 2020, from https://id.wikipedia.org/wiki/Demografi_Indonesia

Ihsan, M. M. (1996). Humanisme Spiritual, Antagonisme atau Integralisme Sejarah. Jurnal Filsafat.

Iyyadh, A. M. U. (1904). Nasim al-Riyadh fi Sharh Shifa' al-Qadhi 'Iyyadh. Al-Azhar.

Jahroni, J. (2020). Saudi Arabia Charity and the Institutionalization of Indonesian Salafism. Al-Jami'ah Journal of Islamic Studies, 58(1). https://doi.org/10.14421/ajis.2020.581.35-62

Kathir, A. F. I. (1999). Tafsir al-Qur'an al- 'Azim. Dar al-Thaybah.

Luman. Indian Caste System. Cultural Anthropology. Retrieved August 30, 2020, from https://courses.lumenlearning.com/culturalanthropology/chapter/indian-caste-system/

Madjid, N. (1992). Islam: Doktrin dan Peradaban. Yayasan Wakaf Paramadina.

Madjid, N. (1994). Pintu-pintu Menuju Tuhan. Yayasan Wakaf Paramadina.

Mughofar, J. K. (2016). Sejarah Pemikiran Modern dalam Islam. Retrieved July 30, 2020, from https://www.academia.edu/26638840/SEJARAH_PEMIKIRAN_MODERN_DALAM_ISLAM

Mursi, M. M. (1995). Al-Idarah al-Madrasiyyah al-Hadithiyyah. 'Alim al-Kitab.

Naji, U. S. (n. d.). Tarikh Thaurat al-Islah wa al-Irsyad bi Indunisia.

Perserikatan Al-Irsyad. (1932). Titel Sajjid Djadi Oeroesan Pemerintah Tjampur Tangan, Keterangan dan Penerangan Djelas Tentang Hak dan Hoekoem Jang Njata di Dalam Islam. Centrum.

PP Al-Irsyad. (2000). Mabadi al-Irsyad. PP Al-Irsyad.

PP Al-Irsyad. (2018). Al-Irsyad Al-Islamiyah Anggaran Dasar Anggaran Rumah Tangga. PP Al-Irsyad.

Shahab, Y. Z. (2005). Sistim Kekerabatan sebagai Katalisator Peran Ulama Keturunan Arab di Jakarta. Jurnal Antropologi Indonesia, 29(2).

Shihab, M. Q. (1996). Wawasan al-Qur'an: Tafsir Maudhu'i atas Pelbagai Persoalan Umat. Mizan. 


\section{Copyrights}

Copyright for this article is retained by the author(s), with first publication rights granted to the journal.

This is an open-access article distributed under the terms and conditions of the Creative Commons Attribution license (http://creativecommons.org/licenses/by/4.0/). 